\title{
A meta-analysis of pesticide loss in runoff under conventional tillage and no-till management
}

AUTHORS: Daniel Elias, Lixin Wang, Pierre-Andre Jacinthe*

ADDRESSES OF AUTHORS:

${ }^{a}$ Department of Earth Sciences, Indiana University Purdue University, Indianapolis, IN 46202

CORRESPONDING AUTHOR:

*Dr. Pierre-André Jacinthe, Department of Earth Sciences, Indiana University Purdue University

Indianapolis (IUPUI), 723 W. Michigan Street, SL 118, Indianapolis, IN 46202

Phone: (317) 274-7969; Fax: (317) 274 7966; E-mail: pjacinth@iupui.edu

This is the author's manuscript of the article published in final edited form as:

Elias, D., Wang, L., \& Jacinthe, P.-A. (2018). A meta-analysis of pesticide loss in runoff under conventional tillage and no-till management. Environmental Monitoring and Assessment, 190(2), 79. https://doi.org/10.1007/s10661-017-6441-1 


\begin{abstract}
Global agricultural intensification has led to increased pesticide use (37-fold from 1960 to 2005) and soil erosion (14\% since 2000). Conservation tillage, including no-till (NT) has been proposed as an alternative to conventional plow till (PT) to mitigate soil erosion, but past studies have reported mixed results on the effect of conservation tillage on pesticide loss. To explore the underlying factors of these differences, a meta-analysis was conducted using published data on pesticide concentration and load in agricultural runoff from NT and PT fields. Peer-reviewed articles (1985-2016) were compiled to build a database for analysis. Contrary to expectations, results showed greater concentration of atrazine, cyanazine, dicamba, and simazine in runoff from NT than PT fields. Further, we observed greater load of dicamba and metribuzin, but reduced load of alachlor from NT fields. Overall, the concentration and load of pesticides were greater in runoff from NT fields, especially pesticides with high solubility and low affinity for solids. Thus, NT farming affects soil properties that control pesticides retention and interactions with soils, and ultimately their mobility in the environment. Future research is needed for a more complete understanding of pesticide-soil interactions in NT systems. This research could inform the selection of pesticides by farmers, and improve the predictive power of pesticide transport models.
\end{abstract}

Keywords: tillage, octanol-water partition coefficient, solubility, $\mathrm{pH}$, soil organic matter, texture 


\section{Introduction}

Agricultural production has increased in response to the demand for food, fuel, and fiber by an increasing global human population (Spiertz and Ewert 2009). By 2050, the world population is projected to reach 9 to 10 billion people, and most of this growth is expected to occur in developing countries where the demand for food is likely to increase by $70 \%$ (Wik et al. 2008). For example, in response to increased demand for food, global land area devoted to corn production has expanded from 136.36 million hectares in 2000 (USDA 2002) to 177.37 million hectares in 2015 (USDA 2016).

In response to this intensification of agriculture, there has been an increase in the application of agrochemicals, including pesticides and other phytosanitary products for crop protection. From 1982 to 2007, pesticides expenditure increased by 49\% in the U.S. (Grube et al. 2011), and the global pesticide production is projected to increase 300\% by 2050 (Tilman et al. 2001). Similarly, pesticides application to major crops in the U.S. (including corn, soybean, potatoes, cotton and wheat) increased from 196 million to 516 million pounds of active ingredient between 1960 and 2008 (Fernandez-Cornejo et al. 2014). Because of their widespread application and their potential impact on aquatic biota and human health, the export of pesticides to streams in agricultural watersheds has long been an environmental concern (Cope 1966; Rinsky et al. 2012). These concerns are further reinforced by the frequent detection of pesticides at environmentally-relevant concentrations (i.e., pesticide concentration that can have negative effects on organisms; WHO 2002) in agricultural basins across the US, especially corn-growing areas (Larson et al. 1999; USEPA 2016). Different strategies have been proposed to reduce the export of pesticides from agricultural fields into streams, including installation of grass filter strips, contour plowing and reduced tillage (Carter 2000). 
Tillage operations are performed to prepare cropland for planting. Tillage has also been used, with mixed success, as a weed control method (Teasdale et al. 1999; Blackshaw et al. 1994; Mishra and Singh 2012). Conventional tillage (e.g., moldboard plow and disk harrow) is a mechanical operation that primary incorporates fertilizers, lime, and crop residues into the soil (Aletto et al. 2010). Under conventional tillage (plow till, PT), soils are generally more susceptible to water and wind erosion (Phillips et al. 1980). Soil erosion leads the loss of top soil, and reduced soil fertility, as well as increased pollution and sedimentation of streams (Gebhardt et al. 1985).

In response to soil degradation concerns, conservation tillage practices have been adopted in agricultural regions around the world. The main objective of these practices is to leave at least $30 \%$ of the soil surface covered with crop residues to reduce soil erosion by water, or at least 1.1 ton of crop residue ha ${ }^{-1}$ to reduce soil erosion by wind (Aletto et al. 2010). Adoption of conservation tillage practices has generally resulted in improved soil structure, drainage, waterholding capacity, and thus could reduce the risk of surface water pollution by agricultural runoff containing nutrients, sediments, and pesticides (Holland 2004; Knowler and Bradshaw 2007). Various versions of conservation tillage are implemented in agricultural regions, including no-till (no physical disturbance of soil except for the small slits created to drop crop seeds), ridge till (crops are planted on ridges 10-15 cm high), and mulch till (a form of non-inversion tillage that leaves crop residues evenly spread on soil surface) (USDA - NRCS 2016). As concerns over soil erosion and export of agrochemicals to streams become more acute, more farmers have adopted conservation practices including no-till, ridge till, and mulch till. In the U.S., the rate of no-till (NT) adoption has grown from 26\% in 1990 (CTIC 2016a) to 41\% in 2008, while conventional tillage (PT) has decreased from 49\% to 37\% during that same period (CTIC 2016b). 
Pesticides are exported to streams by runoff, leaching, and spray drift (Carter 2000; Rice et al. 2001). Once pesticides enter freshwater ecosystems they can potentially induce a wide range of adverse effects on aquatic organisms (McMahon et al. 2012, Elias and Bernot 2014), wildlife (Hayes et al. 2006), and humans (Rinsky et al. 2012). Decades of ecotoxicological research has been conducted to document the adverse effects of pesticides on biota (Gallagher et al. 1992, Hayes et al. 2006, Hernandez et al. 2012). However, there is a significant knowledge gap in regard to our understanding of the factors influencing the export of pesticides into streams, and more importantly of the effectiveness of conservation tillage practices in reducing pesticide movement in agricultural soils. Because agricultural runoff volume generally decreases with adoption of conservation tillage, it is expected that NT adoption would lead to a reduction in the amount of pesticide transported to streams draining agricultural landscapes. However, studies have reported contradictory results, and this could be due to the combined effects of climate, soil conditions, and physicochemical properties of pesticides on the behavior of these agro-chemicals in soils (Reddy et al. 1995). While, for example, the sorption capacity of soils for cyanazine was not affected by tillage (Reddy et al. 1997), fast rate of alachlor sorption was observed with soils under conservation tillage (Locke 1998). The effect of tillage practices on accessibility of pesticides to sorption sites and their availability in the soil solution could play a significant role in determining the impact of land management on the mobility of pesticides in the environment (Ochsner et al. 2006).

When assessing the effectiveness of conservation tillage in reducing nutrients and pesticides in runoff, two parameters are often reported: pesticide concentration and load (e.g., Bundy et al. 2001; Pantone et al. 2006). Concentration is used to determine compliance with water quality standards, and to address toxicity levels to biota (Stephan et al. 1985). For example, the 
maximum concentration level (MCL) for atrazine is $3 \mu \mathrm{g} \mathrm{L}^{-1}$ in drinking water. Acute exposure above this MCL is likely to cause congestion of heart, lung and kidney, and low blood pressure in humans. With long-term exposure above the MCL, atrazine has the potential to cause cardiovascular damage, retinal and muscular degeneration, and cancer (EPA 1995). Load is used to determine the Total Maximum Daily Load (TMDL) for a particular watershed, which establishes the maximum amount of a pollutant in a water body (Houck 2002). For example, TMDLs were developed for chlorpyrifos, diazinon, and malathion for urban and agricultural lands in the Calleguas Creek watershed in California (Pedersen et al. 2006).

Overall, despite the wide adoption of conservation tillage methods, their impact on the environmental fate of pesticides in soils under no-till is poorly understood, and a comprehensive review is needed to compare the export of pesticides in runoff from agricultural fields under conventional and conservation tillage (i.e., no-till). Therefore, in this meta-analysis, we examined the following questions: 1) how do conventional tillage and conservation tillage affect pesticide concentration and load in agricultural runoff?, and 2) how do pesticides physicochemical characteristics and soil properties influence pesticide concentration and load in runoff under conventional tillage and conservation tillage? We hypothesized that: (1) the concentration and amount of pesticides transported in runoff would be reduced under no-tillage relative to conventional tillage due to greater organic matter content, greater pesticide retention capacity and lesser runoff volume under NT, and (2) pesticides with high water solubility (low $\mathrm{K}_{\text {ow) }}$ ) would be present at greater concentration than pesticides with low solubility (and high $\mathrm{K}_{\text {ow }}$ ). We also anticipated that improved retention of pesticides in NT soils could be a consequence of the progressive increase in soil acidity and enhanced ionic adsorption of pesticide onto soil particles. 


\section{Methods}

Selection of articles for this meta-analysis was based on whether a particular study investigated pesticide concentration and load in agricultural runoff from fields under conventional tillage and no-till. We used the Web of Science and Google Scholar search engines to locate peer-reviewed journal articles on these topics published in English from 1985 to 2016. The search included individual and combinations of terms such as "no-till”, “conventional till”, “pesticides” (e.g., atrazine, metolachlor, 2,4-D), “runoff”, “tillage management”. The main criteria for data compilation was that the articles reported values of pesticide concentration and/or load in runoff under no-till and conventional tillage practices under field conditions. We excluded conference proceedings, unpublished manuscripts, presentations, and posters. Data from selected studies were compiled into a database. Throughout this paper, concentration is reported in unit $\mu \mathrm{g} \mathrm{L}^{-1}$ and load as $\mathrm{g} \mathrm{ha}^{-1}$. From the initial pool of studies $(\mathrm{n}=87)$, we narrowed the results to studies that defined no-till as zero tillage. Since our focus was on understanding the effects of no-till on pesticide concentration and load, we excluded studies that compared conventional tillage to other conservation tillage practices (e.g., mulch tilling, reduced till). For this study, conventional tillage includes a range of practices such as ploughing, disking, and moldboard (Table 1; final number of studies: $\mathrm{n}=34$ ).

Pesticide concentration data reported in these studies were obtained using a variety of collection protocols including trays, concrete channels on the edge of fields, automatic samplers, and sump pumps. Spatial sampling dimensions in these studies ranged from experimental plots ( $2 \mathrm{~m}^{2}$ to $100 \mathrm{~m}^{2}$ ), fields (400 $\mathrm{m}^{2}$ to $<6500 \mathrm{~m}^{2}$ ), and watersheds (122 ha). Overall, these studies assessed the effects of tillage on pesticide concentration in runoff (observational studies) and did not 
assess the influence of other variables, including pesticide application rate and application technique, crop species, and type of crop residues. Thus, our meta-analysis can provide insights on the effect of tillage practices on the mobility of pesticides independently of these aforementioned factors. In addition, due to the inclusion of data from varied sources, our results can be applicable to a wide range of pesticides and soil conditions.

From each study, soil properties (i.e., texture, organic matter content, and $\mathrm{pH}$ ) and pesticide physicochemical properties (i.e., solubility and octanol-water partition coefficient) were collected (Table 2). Octanol-water partition coefficient $\left(\mathrm{K}_{\mathrm{ow}}\right)$ is the ratio of a pesticide concentration in octanol relative to its concentration in water. The $\mathrm{K}_{\mathrm{ow}}$ is generally expressed as "log $\mathrm{K}_{\text {ow"; }}$; pesticides with "log $\mathrm{K}_{\text {ow" }}$ " values greater than 3 are likely to be adsorbed to soils and organisms (Linde 1994). Pesticides octanol-water partition coefficient categories selected for this meta-analysis are used by the U.S. Environmental Protection Agency (e.g., USEPA 2016) and adapted from Lewis et al. (2016). Categories included: low (<2.7), moderate (2.7 - 3), and high (> 3). Pesticides solubility was categorized as high $\left(>500 \mathrm{mg} \mathrm{L}^{-1}\right)$, moderate $\left(50-500 \mathrm{mg} \mathrm{L}^{-1}\right)$ and low $\left(<5 \mathrm{mg} \mathrm{L}^{-1}\right)$, and was adopted from the University of Hertfordshire - Pesticide Properties Database (2017) and Lewis et al. (2016).

Soil organic matter content categories were adapted from the Soil Science Division Staff (2017), and included: very low (<1.2\%), low (1.3\% - 2.2\%), moderate (2.3\% - 3.7\%), high (3.8\% 5.2\%), and very high (> 5.2\%). Five categories of soil texture, as defined by the Soil Science Division Staff (2017) and Coche (1986), were used in the meta-analysis. Categories included coarse (sandy soil), moderately coarse (coarse sandy loam, sandy loam, and fine sandy loam), medium (very fine sandy loam, loamy, silty loam, and silty), moderately fine (clay loam, sandy clay loam, silty clay loam), and fine (sandy clay, silty clay, and clay). Categories for $\mathrm{pH}$ were 
obtained from Horneck et al. (2011) and Soil Science Division Staff (2017), and included strongly acidic (< 5.1), moderately acidic (5.2 - 6), slightly acidic (6.1 - 6.5), neutral (6.6 - 7.3), moderately alkaline (7.4 - 8.4), and strongly alkaline (> 8.5).

As part of our meta-analysis evaluation, confidence intervals were constructed to assess the variability of the impact of each categorical variable on pesticide mobility. In order to include those studies that did not report sample size or standard deviation, we performed an unweighted analysis using the log response ratio $(\operatorname{lnR})$ to calculate bootstrapped confidence limits using the statistical software MetaWin 2.0 (sensu Daryanto et al. 2015). The MetaWin software is widely used for meta-analysis of data in diverse scientific disciplines (Kessel et al. 2013; McDaniel et al. 2014; Daryanto et al. 2017). Most meta-analyses studies used unweighted analysis in order to include studies that do not report sample size or standard deviations (unweighted analysis).

Overall, unweighted and weighted analyses generate similar estimates for variance, indicating no significant bias (Fuller and Hester 1999; Gurevitch and Hedges 1999; Nakagawa and Lagisz 2016).

The response ratio is the ratio between the outcome of experimental group (i.e., no-till) to that of the control group (i.e., conventional till). This parameter was used to estimate the proportional changes resulting from tillage cessation. Bootstrapping was iterated 9999 times to improve the probability that the confidence interval is calculated around the cumulative mean effect size for each categorical variable. We use the calculated bootstrap confidence intervals (CI) to address two questions: 1) are there significant differences within categories (e.g., Pesticide solubility: High, Moderate, Low), and 2) are there significant differences between no-till and conventional tillage. The difference within categorical variables is considered significant if the bootstrap confidence intervals do not overlap with each other using a statistical significance level of $\mathrm{P}<$ 
0.05. The difference between no-till and conventional tillage is considered significant if the $95 \%$ CI does not overlap zero (sensu Curtis et al. 1998; Lu et al. 2016).

\section{Results}

\subsection{Pesticides concentration}

Mean pesticides concentration in runoff ranged from $<0.1$ to $12,450 \mu \mathrm{g} \mathrm{L}^{-1}$ in NT soils, and from 600 to 49,810 $\mathrm{ug} \mathrm{L}^{-1}$ in PT soils (Table 3). In NT soils, maximum reported pesticide concentration was $130,700 \mu \mathrm{g} \mathrm{L}{ }^{-1}$ for atrazine, and the lowest concentrations were below detection limit for atrazine, butylate, dicamba, and simazine. In PT soils, the maximum

concentration was $150,100 \mu \mathrm{g} \mathrm{L}^{-1}$ for atrazine, and the lowest concentration was $<0.1 \mu \mathrm{g} \mathrm{L}{ }^{-1}$ for dicamba. The meta-analysis results showed greater concentration of atrazine, cyanazine, dicamba, and simazine under NT relative to PT soils (confidence intervals did not overlap zero; Figure 1A). The concentration of no other pesticide was influenced by tillage management. When comparing all the pesticides, there were no concentration difference between pesticides (overlapping confidence intervals) under no-till. Soil properties including texture, organic matter content, and soil $\mathrm{pH}$ influenced pesticide movement and ultimately affected pesticide concentration in runoff under different tillage management practices. Specifically, pesticide concentration significantly increased in moderately-fine and medium-textured soils under no-till (Figure 2A). Pesticide concentration in fine and coarse soils was not influenced by tillage management.

Similarly, we observed that soils with very-low, low, and medium soil organic matter content had a greater pesticide concentration under NT relative to PT (Figure 3A). No other organic 
matter content categories influenced pesticides concentration under NT. There was no significant difference between tillage practices with respect to pesticide concentration at sites that have very-low, low, and medium soil organic matter content. We also found a clear effect of soil pH on pesticides concentration, with generally increased concentration in acidic (i.e., slightly acidic and moderately acidic) and moderately alkaline soils under no-till (Figure 4A). For neutral soils under no-till management, our analysis did not show measurable influence of land management on pesticide concentration in runoff.

Physicochemical properties of pesticides such as the octanol-water partition coefficient $\left(\mathrm{K}_{\mathrm{ow}}\right)$ and solubility influenced the movement and concentration of pesticides in runoff from no-till fields. Most notably, for pesticides with low and moderate affinity for solids, we observed an increase in runoff concentration under NT. However, for pesticides with high affinity for particles (high $\mathrm{K}_{\text {ow }}$ pesticides), there was no significant effect of no-till management (Figure 5A). Likewise, pesticide concentration in runoff under no-till increases with water solubility of pesticides (Figure 6A).

\subsection{Pesticides load}

Mean pesticide load in runoff ranged from $<0.1 \mathrm{~g} \mathrm{ha}^{-1}$ to $112 \mathrm{~g} \mathrm{ha}^{-1}$ in NT fields and $<0.1 \mathrm{~g}$ $\mathrm{ha}^{-1}$ to $120 \mathrm{~g} \mathrm{ha}^{-1}$ in PT fields (Table 4). For alachlor for example, the maximum pesticide load was $166 \mathrm{~g} \mathrm{ha}^{-1}$ and $219.7 \mathrm{~g} \mathrm{ha}^{-1}$ under NT and PT management practice, respectively. Overall, results of this meta-analysis showed that under NT management the load of dicamba and metribuzin increased, whereas alachlor load significantly decreased (Figure 1B). No other pesticide load was significantly affected by tillage management. 
Pesticide loads increased in moderately-fine and fine-textured soils, and decreased in medium textured soils under NT (Figure 2B). Pesticide loads in coarse and moderately-coarse soils were not influenced by tillage management. Further, pesticide loads under NT were generally greater in soils with medium soil organic matter (Figure 3B), and in moderately acidic and neutral soils (Figure 4B). Pesticide loads were not significantly different between neutral and moderately acidic soils under no-till. In contrast, pesticide loads decreased in slightly acidic NT soils (Figure 4B).

Pesticide octanol-water partition coefficient and solubility influenced pesticide loads in notill soils. Specifically, for pesticides with low affinity for solids (low $\mathrm{K}_{\mathrm{ow}}$ ) and high water solubility (Figure 6B), pesticide loads significantly increased under NT (Figure 5B). For moderately-soluble pesticides, pesticide load significantly decreased under NT (Figure 6B). There were no significant difference between moderate and high $\mathrm{K}_{\text {ow }}$ (affinity for particles) pesticides with in terms of their behavior in NT soils (Figure 5B). In contrast, we observed significant differences between moderate and high water-solubility pesticides with respect to pesticide load (Figure 6B).

\section{Discussion}

Numerous studies have been conducted to assess the influence of conservation tillage on pesticide transport via surface runoff (e.g., Donigian and Carsel 1987; Basta et al. 1997; Mickelson et al. 2001; Aletto et al. 2010). Taken individually, these studies have not yielded a consistent conclusion. We conducted a more comprehensive meta-analysis to summarize results of past studies and identify emerging patterns. Because the primary purpose of conservation tillage is to reduce soil erosion and surface runoff volume (Gebhardt et al. 1985), there was an 
expectation of reduced amount of pesticide transport in runoff under NT relative to PT (Berenzen et al. 2005; Battaglin et al. 2011; Fiener et al. 2011). However, our results showed that NT has limited effect in reducing the concentration and load for most pesticides in runoff (Figure1). Although our results are quite variable, probably due to the diversity of data sources, this conclusion is in agreement with results reported by Isensee and Sadeghi (1993) from a 2-year field experiment comparing the mobility of several pesticides at sites under NT and PT management. Results of that study have also shown that the time gap between pesticide application and rainfall event was more important than tillage practice in determining the amount of pesticides lost in runoff (Insensee and Sadeghi, 1993). Aguiar et al. (2015) concluded that vegetated buffer trips provide an effective to mitigate the transport of pesticides in agricultural runoff. Although water volume is a key factor influencing pesticide load, and that no-till farming has demonstrated effect in reducing runoff volume, other factors such as local hydrology (Insensee and Sadeghi, 1993) and pesticide chemistry (Moore et al., 2014) could have the overriding effect in determining pesticide load from agro-ecosystems. We therefore argue that the results of our meta-analysis should be interpreted with consideration of physicochemical properties of different types pesticides ( $\mathrm{K}_{\mathrm{ow}}$ and solubility) along with an understanding of the influence of no-till on soils properties (i.e., organic matter content, $\mathrm{pH}$ ). The combination of these factors determine the distribution of pesticides between the solid phase and the soil solution, and ultimately their fate in the environment.

No-till management influences soil organic matter content and soil pH (Logan et al. 1991; Duiker and Myers 2016) and they likely play a key role in determining the transport of pesticides from NT soils (Aletto et al. 2010). Likely due to the accumulation of crop residue on land surface, NT farming generally leads to an increase in organic matter content (Karlen et al. 1994), 
and studies have shown that, for most pesticides, adsorption is directly related to organic matter content (Bollag et al. 1992; Linde 1994). In no-till soils, however, the relationship between organic matter and pesticide mobility appears more complex. Inspection of our meta-analysis results, suggests that $2.3 \%$ organic matter content is a threshold above which our hypothesized impact of NT on pesticide mobility could hold. Specifically, our results showed that NT soils with $<2.3 \%$ organic matter content are often associated with increasing pesticide concentration and load in runoff (Figure 3), likely due to the combined effect of soil organic matter and $\mathrm{pH}$. Soils with low organic matter content have less propensity to retain pesticides (Linde 1994). In addition, pesticide mobility could be further amplified if acidic soil conditions begin to develop. Low soil $\mathrm{pH}$, in part due to organic matter decomposition, could induce reduced retention of pesticides in soils, and thus indirectly create an environment that favors the transport of these compounds in agricultural runoff (Linde 1994).

Under no-till management, soil pH often evolves toward acidic conditions (Logan et al. 1991) in response to increase in organic matter, particularly organic acids, and changes in soil cations balance (Thomas et al. 2007). Further, pesticide mobility generally increases with increased solubility and reduced adsorption of pesticides to solid phases (Berenzen et al. 2005), and these factors are strongly influenced by soil pH (Linde 1994; Sheng et al. 2005). These considerations would explain, at least partly, the results (Figure 4) of our meta-analysis - that is, greater pesticide concentration and load under no-till management. We observed increased pesticide concentrations and loads in circumneutral $(\mathrm{pH}<7.3)$ and alkaline soils $(7.4-8.4)$, and decreased pesticide load in slightly acidic soils $(6.1-6.5)$ under no-till. Soil pH can alter the physicochemical properties (e.g, pKa, polarity) of pesticides and their behavior in soils. 
The sorption of pesticides by soil can be a pH-dependent process depending on the chemical structure of a given pesticide (Sheng et al. 2005). The dissociation constant (pKa) of pesticides determines their polarity and potential movement at different soil pH (Kah and Brown 2007). For pesticides with a $3<$ pKa $<10$ (e.g., 2,4-D, MCPA, bromoxynil) and pKa $>10$ (e.g., carbaryl, cyanazine), their mobility and solubility are pH-sensitive (Kah and Brown 2007). For example, 2,4-D and bromoxynil are in a neutral form at $\mathrm{pH}<6$, and anionic form at $\mathrm{pH}>6$. Anionic pesticides such as 2,4-D and bromoxynil exhibit enhanced transport in acidic conditions, and increased adsorption in more alkaline soils(Sheng et al. 2005). Overall, the interactions of soil $\mathrm{pH}$ and physicochemical properties of pesticides determine their mobility in the environment.

Clay particles provide a larger surface area than silt or sand-sized particles for the sorption of nutrients and pesticides (Bruand and Tessier 2010). Thus, high clay content increases pesticide retention and reduces pesticide mobility (Koskinen and Clay 1997). In addition to geo-reactive surfaces such as organic matter and clay particles, pesticide mobility is also governed by their intrinsic physicochemical properties (i.e., octanol-water partition coefficient and solubility). In general, pesticide load increases low $\mathrm{K}_{\mathrm{ow}}$ and decreased retention by soil colloids (Wauchope et al. 1992; Linde 1994; Berenzen et al. 2005). For example, pesticides with high water solubility tend to be present at high concentration in runoff (Basta et al. 1997; Hansen et al. 2001). In contrast, pesticides with high affinity for soil particles (high $\mathrm{K}_{\text {ow }}$ ) generally exhibit increased soil retention capacity and tend to be present at low concentration in runoff (Wauchope et al. 1992; Linde 1994; Berenzen et al. 2005). This line of reasoning is consistent with the results (Figures 5 and 6) of our meta-analysis - increased concentration and load for pesticides with high solubility and low affinity for solids. 


\section{Conclusions}

The positive effect of no-till (NT) on soil erosion and soil health is widely documented, but questions remain regarding its relative impact (compared to conventional plow-till, PT) on pesticide loss from agroecosystems. Contrary to expectations, our results showed that NT management was not effective in limiting these losses. For most pesticides, especially those with high solubility and low affinity for solids, their concentration in runoff was consistently greater under NT than PT. We concluded that soil properties influenced by no-till practices (i.e., organic matter and $\mathrm{pH}$ ) play an important role in determining the distribution of pesticides between the soil solution and the solid phase and, consequently, their potential transport via surface runoff. The physicochemical properties of different classes of pesticides (i.e., $\mathrm{K}_{\text {ow }}$ and solubility) in combination with alterations in soil properties induced by no-till (organic matter, $\mathrm{pH}$ ) ultimately determine the concentration and loads of pesticide measured in agricultural runoff. In our metaanalysis, we observed no-change or increasing pesticide concentration and load under no-till management. We also observed trends of decreasing load under no-till for pesticides with high affinity for soil particles, in soils with $\mathrm{pH}$ in the 6.1 - 6.5 range (slightly acidic), and for

pesticides with moderate solubility (50 - $500 \mathrm{mg} \mathrm{L}^{-1}$ ). Thus, to meet water quality criteria (e.g., pesticide total maximum daily load) as well as to improve the effectiveness of water quality protection programs, no-till management could prove more beneficial in slightly acidic soils (pH around 6.1 - 6.5), and if the pesticides applied are moderately soluble and exhibit high affinity for soil particles. Therefore, predicting the impact of conservation tillage on the fate of pesticides in the environment is a complex task, and clearly requires more research to better elucidate the effect of no-till on the nature and intensity of the interactions between agricultural soils and pesticides. These future studies could inform the decision of agencies involved in water quality 
management, help farmers in the selection of pesticides most appropriate to their farming practices, and improve the predictive power of pesticide transport models.

\section{Acknowledgment}

This research was supported by grants from the Indiana Water Resources Research Center (104B grant, 4107-73618) and USDA-NIFA (2014-51130-22492). The authors thank Dr. Stefani Daryanto for assistance with the MetaWin software package. 


\section{References}

Aguiar, T. R., Bortolozo, F. R., Hansel, F. A., Rasera, K., \& Ferreira, M. T. (2015). Riparian buffer zones as pesticide filters of no-till crops. Environmental Science and Pollution, 22(14), 10618-10626.

Alletto, L., Coquet, Y., Benoit, P., Heddadj, D., \& Barriuso, E. (2010). Tillage management effects on pesticide fate in soils. A review. Agronomy for Sustainable Development, 30(2), 367-400.

Arabi, M., Frankenberger, J. R., Engel, B. A. \& Arnold, J. G. (2008). Representation of agricultural conservation practices with SWAT. Hydrological Processes, 22(16), 30423055.

Bailey, G. W. \& White, J. L. (1970). Factors influencing the adsorption, desorption, and movement of pesticides in soil. In Single Pesticide Volume: The Triazine Herbicides (pp. 29-92). New York: Springer

Baker, J. L., \& Johnson, H. P. (1979). The effect of tillage systems on pesticides in runoff from small watersheds. Transactions of the ASAE, 22(3), 554-559.

Basta, N. T., Huhnke, R. L., \& Stiegler, J. H. (1997). Atrazine runoff from conservation tillage systems: A simulated rainfall study. Journal of Soil and Water Conservation, 52(1), 4448.

Battaglin, W. A., Sandstrom, M. W., Kuivila, K. M., Kolpin, D. W., \& Meyer, M. T. (2011). Occurrence of azoxystrobin, propiconazole, and selected other fungicides in US streams, 2005-2006. Water, Air, \& Soil Pollution, 218(1-4), 307-322. 
Baughman, T. A., Shaw, D. R., Webster, E. P., \& Boyette, M. (2001). Effect of cotton (Gossypium hirsutum) tillage systems on off-site movement of fluometuron, norflurazon, and sediment in runoff. Weed Technology, 15(1), 184-189.

Berenzen, N., Lentzen-Godding, A., Probst, M., Schulz, H., Schulz, R., \& Liess, M. (2005). A comparison of predicted and measured levels of runoff-related pesticide concentrations in small lowland streams on a landscape level. Chemosphere, 58(5), 683-691.

Bollag, J. M., Myers, C. J., \& Minard, R. D. (1992). Biological and chemical interactions of pesticides with soil organic matter. Science of the Total Environment, 123, 205-217.

Bundy, L. G., Andraski, T. W. \& Powell, J. M. (2001). Management practice effects on phosphorus losses in runoff in corn production systems. Journal of Environmental Quality, 30(5), 1822-1828.

Carter, A. (2000). How pesticides get into water-and proposed reduction measures. Pesticide Outlook, 11(4), 149-156.

Cheng, J., Zhang, H., Zhang, Y., Shi, Y., \& Cheng, Y. (2009). Effects of preferential flow on soil-water and surface runoff in a forested watershed in China. Frontiers of Forestry in China, 4(2), 132-139.

Coche, A. G. (1985). Simple methods for aquaculture: Soil and freshwater fish culture. Rome, Italy: Food and Agriculture Organization of the United Nations.

Conservation Technology Information Center. (2016a). Crop Residue Management Survey 2006. http://www.ctic.org/media/pdf/2006\%20CRM\%20summary.pdf. Accessed 1 December 2016. 
Conservation Technology Information Center. (2016b). 2008 Amendment to the National Crop Residue Management Survey Summary. http://www.ctic.org/media/pdf/National\%20Summary\%202008\%20(Amendment).pdf. Accessed 1 December 2016.

Cope, O. B. (1966). Contamination of the freshwater ecosystem by pesticides. Journal of Applied Ecology, 33-44.

Cooke, S. E., Ahmed, S. M. \& MacAlpine, N. D. (2000). Introductory guide to surface water quality monitoring in agriculture. Edmonton, Alberta, Canada: Conservation and development branch, Alberta Agriculture, Food and Rural Development.

Curtis, P. S., \& Wang, X. (1998). A meta-analysis of elevated $\mathrm{CO}_{2}$ effects on woody plant mass, form, and physiology. Oecologia. 113(3), 299-313.

Daryanto, S., Wang, L. \& Jacinthe, P. A. (2015). Global synthesis of drought effects on food legume production. PloS one, 10(6), pe0127401.

Daryanto, S., Wang, L., \& Jacinthe, P.A. (2017). Impacts of no-tillage management on nitrate loss from corn, soybean and wheat cultivation: A meta-analysis. Scientific Reports, 7(1), 12117.

Devlin, D. L., Regehr, D. L. \& Barnes, P. L. (2000). Managing to minimize atrazine runoff. Manhattan, Kansas, USA: Kansas State University Agricultural Experiment Station and Cooperative Extension Service, Manhattan, KS. 
Donigian, A. S., \& Carsel, R. F. (1987). Modeling the impact of conservation tillage practices on pesticide concentrations in ground and surface waters. Environmental Toxicology and Chemistry, 6(4), 241-250.

Duiker, S. W., \& Myers, J. C. (2016). Better soils with the no-till system: A publication to help farmers understand the effects of no-till systems on the soil. Harrisburg, Pennsylvania, USA: Pennsylvania Conservation Partnership. https://vtechworks.lib.vt.edu/bitstream/handle/10919/68815/4533_Duiker2005_better_soi ls_with_noTill.pdf?sequence=1. Accessed in April 12017.

Elias, D., \& Bernot, M. J. (2014). Effects of atrazine, metolachlor, carbaryl and chlorothalonil on benthic microbes and their nutrient dynamics. PloS one, 9(10), pe109190.

Elliott, J. A., Cessna, A. J., Nicholaichuk, W., \& Tollefson, L. C. (2000). Leaching Rates and Preferential Flow of Selected Herbicides through Tilled and Untilled. Journal of Environmental Quality, 29(5), 1650-1656.

El-Sadek, A., Radwan, M. \& Abdel-Gawad, S. (2005). Analysis of Load versus Concentration as water Quality Measures. Sharm El-Sheikk, Egypt: Ninth International Water Technology Conference. https://www.researchgate.net/profile/Alaa_ElSadek/publication/242214845_ANALYSIS_OF_LOAD_VERSUS_CONCENTRATION _AS_WATER_QUALITY_MEASURES/links/02e7e533309788b4c6000000.pdf. Accessed 1 April 2017.

Enserink, M., Hines, P. J., Vignieri, S. N., Wigginton, N. S. \& Yeston, J. S. (2013). The pesticide paradox. Science, 341(6147), 728-729. 
Felsot, A. S., Mitchell, J. K., \& Kenimer, A. L. (1990). Assessment of management practices for reducing pesticide runoff from sloping cropland in Illinois. Journal of Environmental Quality, 19(3), 539-545.

Fernandez-Cornejo, J., Nehring, R. F., Osteen, C., Wechsler, S., Martin, A., \& Vialou, A. (2014). Pesticide use in US agriculture: 21 selected crops, 1960-2008. https://www.ers.usda.gov/webdocs/publications/43854/46734_eib124.pdf?v=41830. Accessed 1 November 2017.

Fiener, P., Auerswald, K., \& Van Oost, K. (2011). Spatio-temporal patterns in land use and management affecting surface runoff response of agricultural catchments-A review. Earth-Science Reviews, 106(1), 92-104.

Fuller, J. B., \& Hester, K. (1999). Comparing the sample-weighted and unweighted metaanalysis: An applied perspective. Journal of Management, 25(6), 803-828.

Gallagher, E. P., Canada, A. T. \& Di Giulio, R. T. (1992). The protective role of glutathione in chlorothalonil-induced toxicity to channel catfish. Aquatic Toxicology, 23(3), 155-168.

Gan, J., Lee, S. J., Liu, W. P., Haver, D. L., \& Kabashima, J. N. (2005). Distribution and persistence of pyrethroids in runoff sediments. Journal of Environmental Quality, 34(3), 836-841.

Gaynor J., \& Bissonnette D. (1992). The effect of conservation tillage practices on the losses of phosphorus and herbicides in surface and subsurface drainage waters. Ontario, Canada: Agriculture Canada Research Station. 
Gaynor, J. D., MacTavish, D. C., \& Fidlay, W. I. (1995). Organic chemicals in the environment. Journal of Environmental Quality, 24, 246-256.

Gebhardt, M. R., Daniel, T. C., Schweizer, E. E., \& Allmaras, R. R. (1985). Conservation tillage. Science, 230, 625-631.

Glenn, S., \& Angle, J. S. (1987). Atrazine and simazine in runoff from conventional and no-till corn watersheds. Agriculture, Ecosystems \& Environment, 18(4), 273-280.

Grube, A., Donaldson, D., Kiely, T. \& Wu, L. (2011). Pesticides industry sales and usage. U.S. EPA, Washington, DC, USA.

Guo, L. (2002). Evaluation of Environmental Models for Assessing Surface Water Contamination by Pesticides. Sacramento, California, USA: Department of Pesticide Regulation. http://www.cdpr.ca.gov/docs/emon/pubs/ehapreps/m041802.pdf. Accessed 1 December 2016.

Gurevitch, J., \& Hedges, L. V. (1999). Statistical issues in ecological meta-analyses. Ecology, 80(4), 1142-1149.

Hall, J. K., Murray, M. R., \& Hartwig, N. L. (1989). Herbicide leaching and distribution in tilled and untilled soil. Journal of Environmental Quality, 18(4), 439-445.

Hall, J. K., Mumma, R. O., \& Watts, D. W. (1991). Leaching and runoff losses of herbicides in a tilled and untilled field. Agriculture, Ecosystems \& Environment, 37(4), 303-314.

Hall, J. K., \& Mumma, R. O. (1994). Dicamba mobility in conventionally tilled and non-tilled soil. Soil and Tillage Research, 30(1), 3-17. 
Hansen, N. C., Moncrief, J. F., Gupta, S. C., Capel, P. D., \& Olness, A. E. (2001). Herbicide banding and tillage system interactions on runoff losses of alachlor and cyanazine. Journal of Environmental Quality, 30(6), 2120-2126.

Hayes, T. B., Stuart, A. A., Mendoza, M., Collins, A., Noriega, N., Vonk, A., Johnston, G., Liu, R. \& Kpodzo, D. (2006). Characterization of atrazine-induced gonadal malformations in African clawed frogs (Xenopus laevis) and comparisons with effects of an androgen antagonist (cyproterone acetate) and exogenous estrogen (17-beta-estradiol): Support for the demasculinization/feminization hypothesis. Environmental Health Perspectives, 114 (Suppl 1), 134.

Hernández, A. F., Parrón, T., Tsatsakis, A. M., Requena, M., Alarcón, R. \& López-Guarnido, O., (2013). Toxic effects of pesticide mixtures at a molecular level: their relevance to human health. Toxicology, 307, 136-145.

Holland, J. M. (2004). The environmental consequences of adopting conservation tillage in Europe: reviewing the evidence. Agriculture, Ecosystems \& Environment, 103(1), 1-25.

Horneck, D. A., Sullivan, D. M., Owen, J. S., \& Hart, J. M. (2011). Soil test interpretation guide. Oregon, USA: Oregon State University, Extension Service.

Houck, O. A. (2002). The clean water act TMDL program: Law, policy, and implementation. Washington, D.C. USA: Environmental Law Institute.

Isensee, A. R., \& Sadeghi, A. M. (1993). Impact of tillage practice on runoff and pesticide transport. Journal of Soil and Water Conservation, 48(6), 523-527. 
Kanwar, R. S., Colvin, T. S., \& Karlen, D. L. (1997). Ridge, moldboard, chisel, and no-till effects on tile water quality beneath two cropping systems. Journal of Production Agriculture, 10(2), 227-234.

Karlen, D. L., Wollenhaupt, N. C., Erbach, D. C., Berry, E. C., Swan, J. B., Eash, N. S., \& Jordahl, J. L. (1994). Long-term tillage effects on soil quality. Soil Tillage Research, 32(4), 313-327.

Kellogg, R. L., Nehring, R. F., Grube, A., Goss, D. W. \& Plotkin, S. (2002). Environmental indicators of pesticide leaching and runoff from farm fields. In Agricultural Productivity (pp. 213-256). New York, US: Springer.

Kenimer, A. L., Mostaghimi, S., Young, R. W., Dillaha, T. A., \& Shanholtz, V. O. (1987). Effects of residue cover on pesticide losses from conventional and no-tillage systems. Transactions of the ASAE, 30(4), 953-959.

Kessel, C., Venterea, R., Six, J., Adviento-Borbe, M. A., Linquist, B., \& Groenigen, K. J. (2013). Climate, duration, and $\mathrm{N}$ placement determine $\mathrm{N}_{2} \mathrm{O}$ emissions in reduced tillage systems: a meta-analysis. Global Change Biology, 19(1), 33-44.

Knowler, D. \& Bradshaw, B. (2007). Farmers’ adoption of conservation agriculture: A review and synthesis of recent research. Food Policy, 32(1), 25-48.

Koskinen, W. C., \& Clay, S. A. (1997). Factors affecting atrazine fate in north central US soils. In Reviews of environmental contamination and toxicology (pp. 117-165). New York, USA: Springer. 
Kurothe, R. S., Kumar, G., Singh, R., Singh, H. B., Tiwari, S. P., Vishwakarma, A. K., et al. (2014). Effect of tillage and cropping systems on runoff, soil loss and crop yields under semiarid rain fed agriculture in India. Soil Tillage Research, 140, 126-134.

Laird, D. A., \& Koskinen, W. C. (2004). Triazine soil interactions. In The Triazine Herbicides (pp. 275-300). San Diego, California, USA: Elsevier.

Larson, S. J., Gilliom, R. J. \& Capel, P. D. (1999). Pesticides in streams of the United States: initial results from the national water-quality assessment program (No. 98-4222). Sacramento, California, USA: US Department of the Interior, US Geological Survey; Branch of Information Services.

Lennartz, B., Louchart, X., Voltz, M., \& Andrieux, P. (1997). Diuron and simazine losses to runoff water in Mediterranean vineyards. Journal of Environmental Quality, 26(6), 14931502.

Levanon, D., Codling, E. E., Meisinger, J. J., \& Starr, J. L. (1993). Mobility of agrochemicals through soil from two tillage systems. Journal of Environmental Quality, 22(1), 155-161.

Lewis, K.A., Tzilivakis, J., Warner, D. \& Green, A. (2016). An international database for pesticide risk assessments and management. Human and Ecological Risk Assessment: An International Journal, 22(4), 1050-1064.

Linde, C.D. (1994). Physico-chemical properties and environmental fate of pesticides. Environmental Hazards Assessment Program, State of California, Environmental Protection Agency, USA. http://www.cdpr.ca.gov/docs/emon/pubs/ehapreps/eh9403.pdf. Accessed 1 December 2016. 
Locke, M. A., Zablotowicz, R. M., Reddy, K. N., \& Steinriede, R. W. (2008). Tillage management to mitigate herbicide loss in runoff under simulated rainfall conditions. Chemosphere, 70(8), 1422-1428.

Logan, T. J., Lal, R., \& Dick, W. A. (1991). Tillage systems and soil properties in North America. Soil Tillage Research, 20(2-4), 241-270.

Logan, T. J., Eckert, D. J., \& Beak, D. G. (1994). Tillage, crop and climatic effects of runoff and tile drainage losses of nitrate and four herbicides. Soil Tillage Research, 30(1), 75-103.

Lu, X., Wang, L., \& McCabe, M. F. (2016). Elevated $\mathrm{CO}_{2}$ as a driver of global dryland greening. Scientific Reports, 6, 20716.

Mamy, L. \& Barriuso, E. (2005). Glyphosate adsorption in soils compared to herbicides replaced with the introduction of glyphosate resistant crops. Chemosphere. 61(6), 844-855.

McDaniel, M. D., Tiemann, L. K., \& Grandy, A. S. (2014). Does agricultural crop diversity enhance soil microbial biomass and organic matter dynamics? A meta-analysis. Ecological Applications, 24(3), 560-570

McMahon, T. A., Halstead, N. T., Johnson, S., Raffel, T. R., Romansic, J. M., Crumrine, P. W. \& Rohr, J. R. (2012). Fungicide-induced declines of freshwater biodiversity modify ecosystem functions and services. Ecology Letters, 15(7), 714-722.

Mickelson, S. K., Boyd, P., Baker, J. L., \& Ahmed, S. I. (2001). Tillage and herbicide incorporation effects on residue cover, runoff, erosion, and herbicide loss. Soil Tillage Research, 60(1), 55-66. 
Moore, M. T., Kröger, R., Locke, M. A., Lizotte, R. E., Testa, S., \& Cooper, C. M. (2014). Diazinon and permethrin mitigation across a grass-wetland buffer. Bulletin of Environmental Contamination and Toxicology, 93(5), 574-579.

Myers, J. L., Wagger, M. G., \& Leidy, R. B. (1995). Chemical movement in relation to tillage system and simulated rainfall intensity. Journal of Environmental Quality, 24(6), 11831192.

Nakagawa, S., \& Lagisz, M. (2016). Visualizing unbiased and biased unweighted meta-analyses. Journal of Evolutionary Biology, 29(10), 1914-1916.

Nakano, Y., Miyazaki, A., Yoshida, T., Ono, K., \& Inoue, T. (2004). A study on pesticide runoff from paddy fields to a river in rural region—1: field survey of pesticide runoff in the Kozakura River, Japan. Water Research, 38(13), 3017-3022.

Nicholls, P. H. (1988). Factors influencing entry of pesticides into soil water. Pest Management Science, 22(2), 123-137.

Pantone, D. J., Potter, K. N., Torbert, H. A., \& Morrison, J. E. (1996). Atrazine loss in runoff from no-tillage and chisel-tillage systems on a Houston black clay soil. Journal of Environmental Quality, 25(3), 572-577.

Pedersen, J. A., Yeager, M. A. \& Suffet, I. H. (2006). Organophosphorus insecticides in agricultural and residential runoff: Field observations and implications for total maximum daily load development. Environmental Science \& Technology, 40(7), 2120-2127.

Prosdocimi, M., Jordán, A., Tarolli, P., Keesstra, S., Novara, A., \& Cerdà, A. (2016). The immediate effectiveness of barley straw mulch in reducing soil erodibility and surface 
runoff generation in Mediterranean vineyards. Science of the Total Environment, 547, 323-330.

Rampazzo-Todorovic, G. R., Rampazzo, N., Mentler, A., Blum, W. E., Eder, A., \& Strauss, P. (2014). Influence of soil tillage and erosion on the dispersion of glyphosate and aminomethylphosphonic acid in agricultural soils. International Agrophysics, 28(1), 93100.

Rector, R. J., Regehr, D. L., Barnes, P. L., \& Loughin, T. M. (2003). Atrazine, S-metolachlor, and isoxaflutole loss in runoff as affected by rainfall and management. Weed Science, 51(5), 810-816.

Reddy, K. N., \& Locke, M. A. (1998). Sulfentrazone sorption, desorption, and mineralization in soils from two tillage systems. Weed Science, 494-500.

Rice, P. J., McConnell, L. L., Heighton, L. P., Sadeghi, A. M., Isensee, A. R., Teasdale, J. R., et al. (2001). Runoff loss of pesticides and soil. Journal of Environmental Quality, 30(5), 1808-1821.

Rinsky, J. L., Hopenhayn, C., Golla, V., Browning, S. \& Bush, H. M. (2012). Atrazine exposure in public drinking water and preterm birth. Public Health Reports, 127(1), 72-80.

River Upper.Pocomake. (2010). Chesapeake Bay Total Maximum Daily Load for Nitrogen, Phosphorus, and Sediment. US Environmental Protection Agency. https://www.epa.gov/sites/production/files/201412/documents/cbay_final_tmdl_exec_sum_section_1_through_3_final_0.pdf. Accessed 1 December 12016. 
Sauer, T. J., \& Daniel, T. C. (1987). Effect of tillage system on runoff losses of surface-applied pesticides. Soil Science Society of America Journal, 51(2), 410-415.

Shaw, D. R., Smith, C. A., \& Hairston, J. E. (1992). Impact of rainfall and tillage systems on offsite herbicide movement 1. Communications in Soil Science \& Plant Analysis, 23(15-16), 1843-1858.

Sheng, G., Yang, Y., Huang, M., \& Yang, K. (2005). Influence of pH on pesticide sorption by soil containing wheat residue-derived char. Environmental Pollution, 134(3), 457-463.

Shipitalo, M. J., Edwards, W. M., \& Owens, L. B. (1997). Herbicide losses in runoff from conservation-tilled watersheds in a corn-soybean rotation. Soil Science Society of America Journal, 61(1), 267-272.

Shipitalo, M. J., \& Owens, L. B. (2006). Tillage system, application rate, and extreme event effects on herbicide losses in surface runoff. Journal of Environmental Quality, 35(6), 2186-2194.

Shipitalo, M. J., Malone, R. W., \& Owens, L. B. (2008). Impact of glyphosate-tolerant soybean and glufosinate-tolerant corn production on herbicide losses in surface runoff. Journal of Environmental Quality, 37(2), 401-408.

Shipitalo, M. J., \& Owens, L. B. (2011). Comparative losses of glyphosate and selected residual herbicides in surface runoff from conservation-tilled watersheds planted with corn or soybean. Journal of Environmental Quality, 40(4), 1281-1289. 
Soil Science Division Staff. (2017). Soil Survey Manual. C. Ditzler, K. Scheffe, and H.C. Monger (Eds.). USDA Handbook 18. Washington, D.C., USA: Government Printing Office.

Spiertz, J. H. J. \& Ewert, F. (2009). Crop production and resource use to meet the growing demand for food, feed and fuel: opportunities and constraints. NJAS-Wageningen Journal of Life Sciences, 56(4), 281-300.

Stephan, C. E., Mount, D. I., Hansen, D. J., Gentile, J. H., Chapman, G. A. \& Brungs, W. A. (1985). Guidelines for deriving numerical national water quality criteria for the protection of aquatic organisms and their uses (p. 98). Duluth, MN, USA: US Environmental Protection Agency.

Triplett, G. B., Conner, B. J., \& Edwards, W. M. (1978). Transport of atrazine and simazine in runoff from conventional and no-tillage corn. Journal of Environmental Quality, 7(1), 7784.

Thomas, G. A., Dalal, R. C., \& Standley, J. (2007). No-till effects on organic matter, pH, cation exchange capacity and nutrient distribution in a Luvisol in the semi-arid subtropics. Soil Tillage Research, 94(2), 295-304.

Tilman, D., Fargione, J., Wolff, B., D'Antonio, C., Dobson, A., Howarth, R., Schindler, D., Schlesinger, W.H., Simberloff, D. \& Swackhamer, D. (2001). Forecasting agriculturally driven global environmental change. Science, 292(5515), 281-284.

United States Department of Agriculture - Natural Resources Conservation Service. 2016. Residue and Tillage management. USDA - NRCS. 
https://www.nrcs.usda.gov/wps/portal/nrcs/detail/national/programs/?cid=nrcs144p2_027

311. Accessed 1 December 2016.

United States Department of Agriculture. 2002. World Agricultural Production. Circular Series

WAP 08-02. Washington D.C., USA: USDA - Foreign Agriculture Service.

United States Department of Agriculture. 2016. World Agricultural Production. Circular Series

WAP 11-17. Washington D.C., USA: USDA - Foreign Agriculture Service.

United States Environmental Protection Agency. 2016. Aquatic life ambient water quality criteria for carbaryl. EPA/820/R-12/007. Washington, DC, USA: Office of Water, Science and Technology,

University of Hertfordshire, Pesticides Properties Database. 2017. Pesticides Properties Database. Agriculture \& Environment Research Unit (AERU) at University of Hertfordshire. Hertfordshire, UK. http://sitem.herts.ac.uk/aeru/ppdb/en/index.htm. Accessed 1 December 2016.

Warnemuende, E. A., Patterson, J. P., Smith, D. R., \& Huang, C. H. (2007). Effects of tilling notill soil on losses of atrazine and glyphosate to runoff water under variable intensity simulated rainfall. Soil Tillage Research, 95(1), 19-26.

Watanabe, H., Watermeier, N. L., Steichen, J. M., Barnes, P., \& Phong, T. K. (2007). Impacts of tillage and application methods on atrazine and alachlor losses from upland fields. Weed Biology and Management, 7(1), 44-54.

Wauchope, R. D., Buttler, T. M., Hornsby, A. G., Augustijn-Beckers, P. W. M., \& Burt, J. P. (1992). The SCS/ARS/CES pesticide properties database for environmental decision- 
making. In Reviews of Environmental Contamination and Toxicology (pp. 1-155). New York: Springer.

Webster, E. P., \& Shaw, D. R. (1996). Off-site runoff losses of metolachlor and metribuzin applied to differing soybean (Glycine max) production systems. Weed Technology, 556564.

Wik, M., Pingali, P. \& Broca, S. (2008). Global agricultural performance: past trends and future prospects. Background paper for the World Development Report. Washington, DC, USA: World Bank.

http://citeseerx.ist.psu.edu/viewdoc/download?doi=10.1.1.697.2420\&rep=rep1\&type=pdf Accessed 1 December 2016.

World Health Organization. (2002). Genomics and world health: report of the Advisory Committee on Health Research. Geneva, Switzerland: World Health Organization. 


\section{Figure captions}

Figure 1. Confidence intervals (CI, 95\%) for the concentration (A) and load (B) of pesticides in runoff expressed as a ratio of no-till relative to conventional till. Intervals that overlap zero indicate no significant influence of tillage management. Differences between pesticides are considered significant if the CIs do not overlap with each other $(\mathrm{P}<0.05)$. Pesticides reported in fewer than two studies were omitted from the analysis with MetaWin 2.0.

Figure 2. Confidence intervals (CI, 95\%) for the concentration (A) and load (B) of pesticides in runoff expressed as a ratio of no-till relative to conventional till. Intervals that overlap zero indicate no significant influence of tillage management. Differences between soil texture are considered significant if the CIs do not overlap with each other $(\mathrm{P}<0.05)$. Soil texture categories includes coarse (sand, loamy sand), moderately coarse (sandy loam), medium (loam, silty loam, silt), moderate fine (loams clay, sandy clay, silty clay), and fine (sandy clay, silty clay, clay).

Figure 3. Confidence intervals (CI, 95\%) for the concentration (A) and load (B) of pesticides in runoff expressed as a ratio of no-till relative to conventional till. Intervals that overlap zero indicate no significant influence of tillage management. Differences between soil organic matter are considered significant if the CIs do not overlap with each other $(\mathrm{P}<0.05)$. Soil organic matter categories were: very low $(<1.2 \%)$, low $(1.3 \%-2.2 \%)$, medium $(2.3 \%-3.7 \%)$, high $(3.8 \%-5.2 \%)$, and very high $(>5.2 \%)$. 
Figure 4. Confidence intervals (CI, 95\%) for the concentration (A) and load (B) of pesticides in runoff expressed as a ratio of no-till relative to conventional till. Intervals that overlap zero indicate no significant influence of tillage management. Differences between soil $\mathrm{pH}$ are considered significant if the CIs do not overlap with each other $(\mathrm{P}<0.05)$. Soil $\mathrm{pH}$ categories were: strongly acidic $(<5.1)$, moderately acidic $(5.2-6)$, slightly acidic $(6.1-6.5)$, neutral (6.6 7.3), moderately alkaline (7.4 - 8.4), strongly alkaline (> 8.5).

Figure 5. Confidence intervals (CI, 95\%) for the concentration (A) and load (B) of pesticides in runoff expressed as a ratio of no-till relative to conventional till. Intervals that overlap zero indicate no significant influence of tillage management. Differences between pesticide octanolwater partition coefficient $\left(\mathrm{K}_{\mathrm{ow}}\right)$ are considered significant if the CIs do not overlap with each other $(\mathrm{P}<0.05)$. Pesticides octanol-water partition coefficient categories were: low $(<2.7)$, moderate $(2.7-3)$, and high $(>3)$.

Figure 6. Confidence intervals (CI, 95\%) for the concentration (A) and load (B) of pesticides in runoff expressed as a ratio of no-till relative to conventional till. Intervals that overlap zero indicate no significant influence of tillage management. Differences between pesticide solubility are considered significant if the CIs do not overlap with each other $(\mathrm{P}<0.05)$. Pesticides solubility categories were: low $\left(<50 \mathrm{mg} \mathrm{L}^{-1}\right)$, moderate $\left(50-500 \mathrm{mg} \mathrm{L}^{-1}\right)$, and high $\left(>500 \mathrm{mg} \mathrm{L}^{-}\right.$ $\left.{ }^{1}\right)$. 

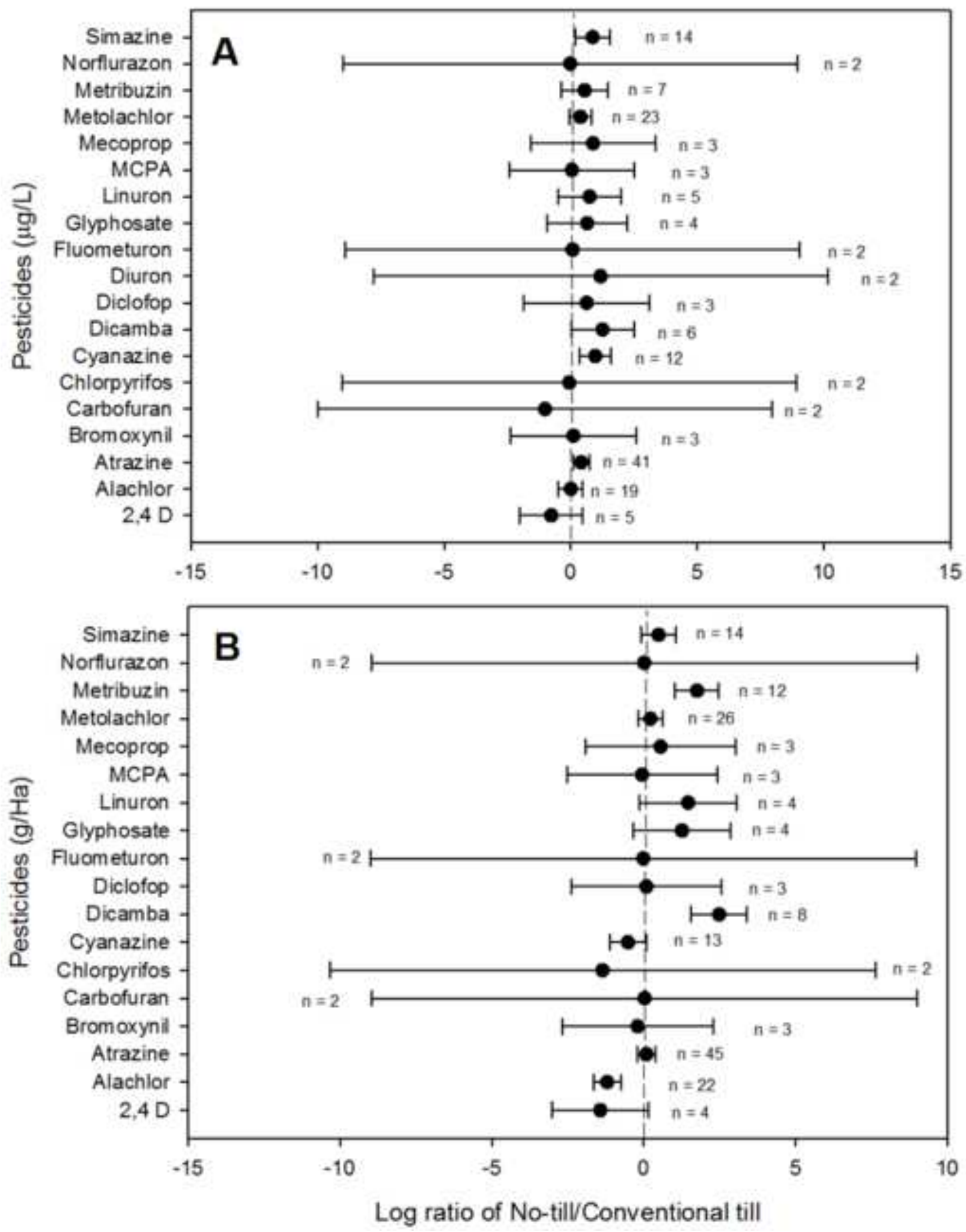

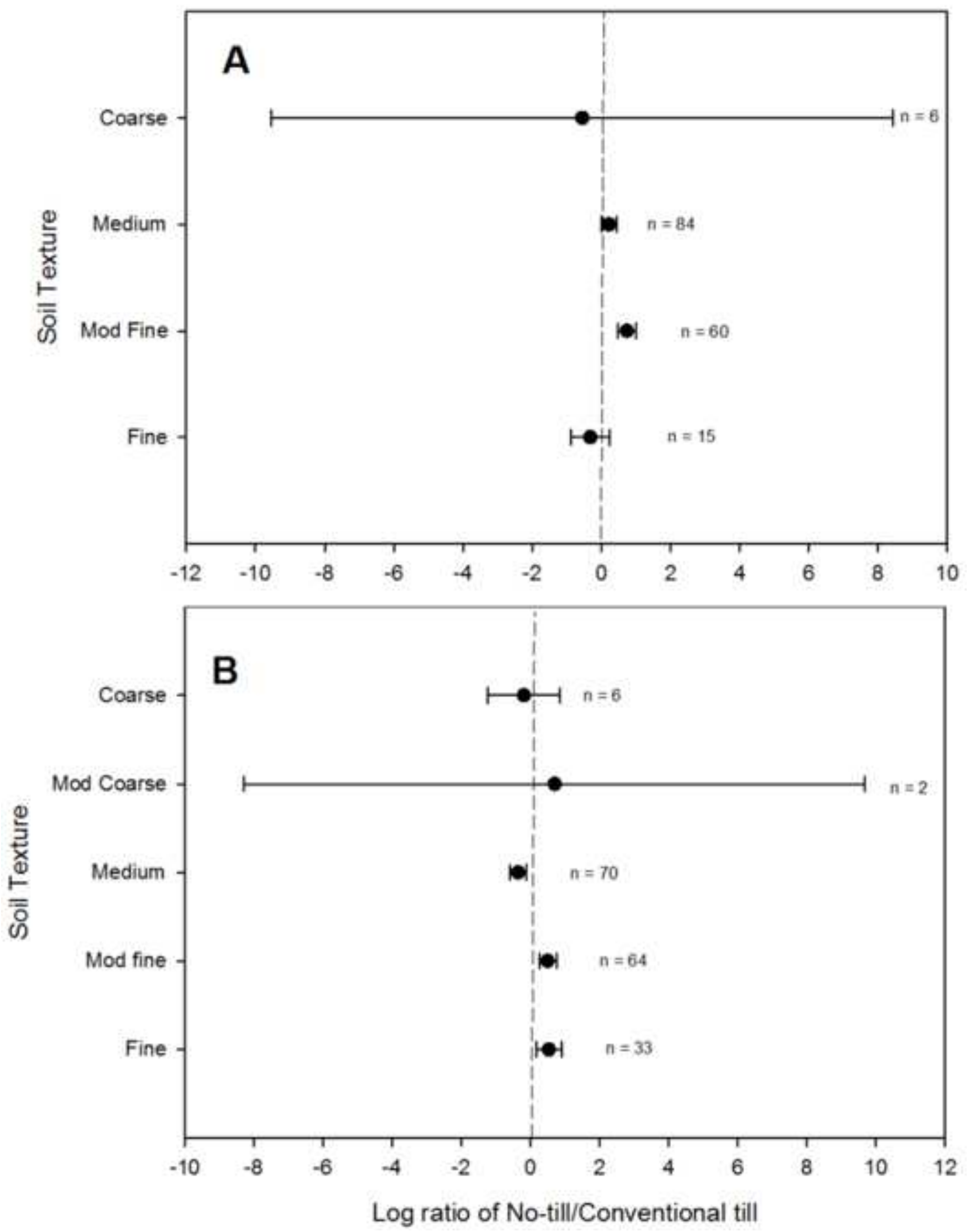

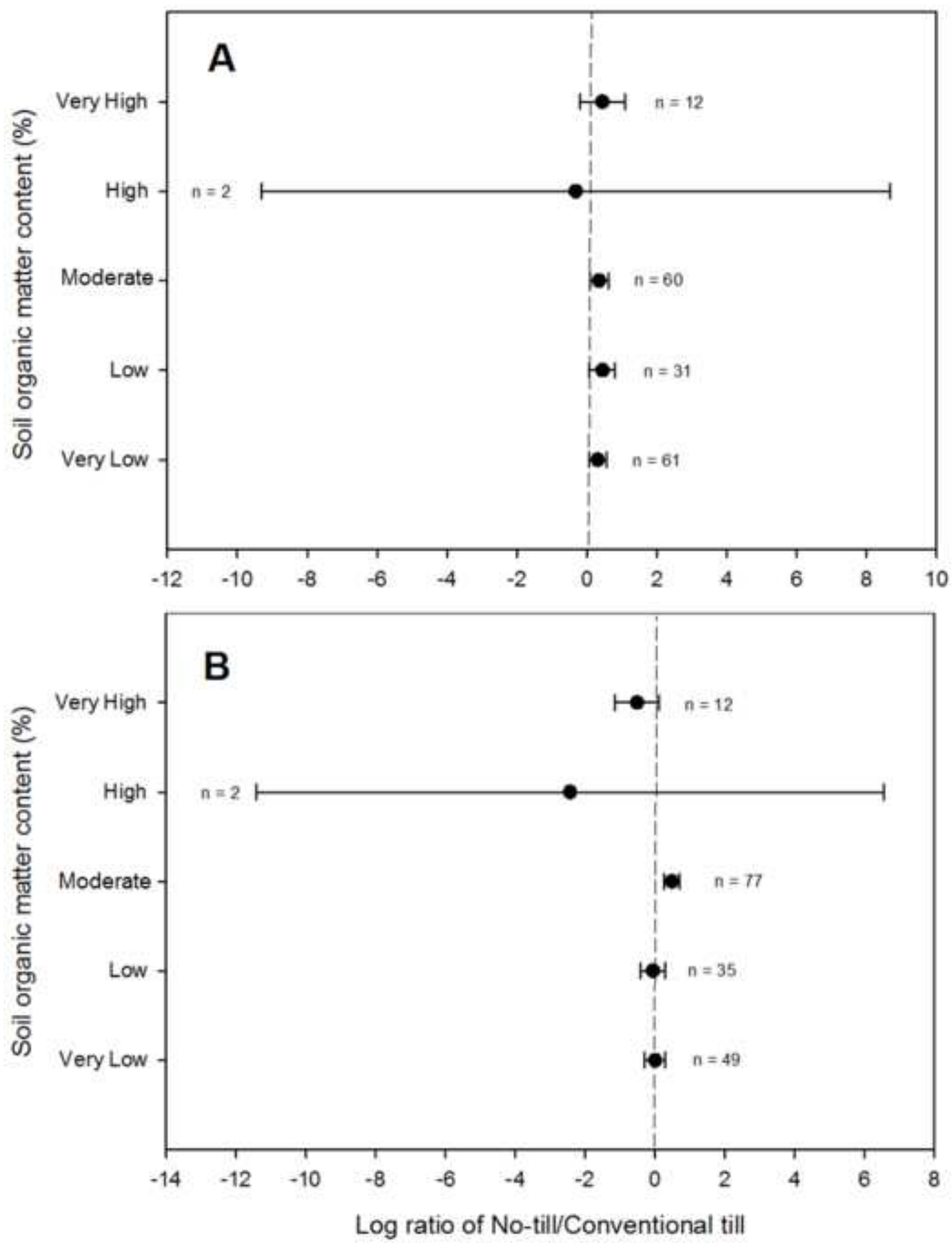

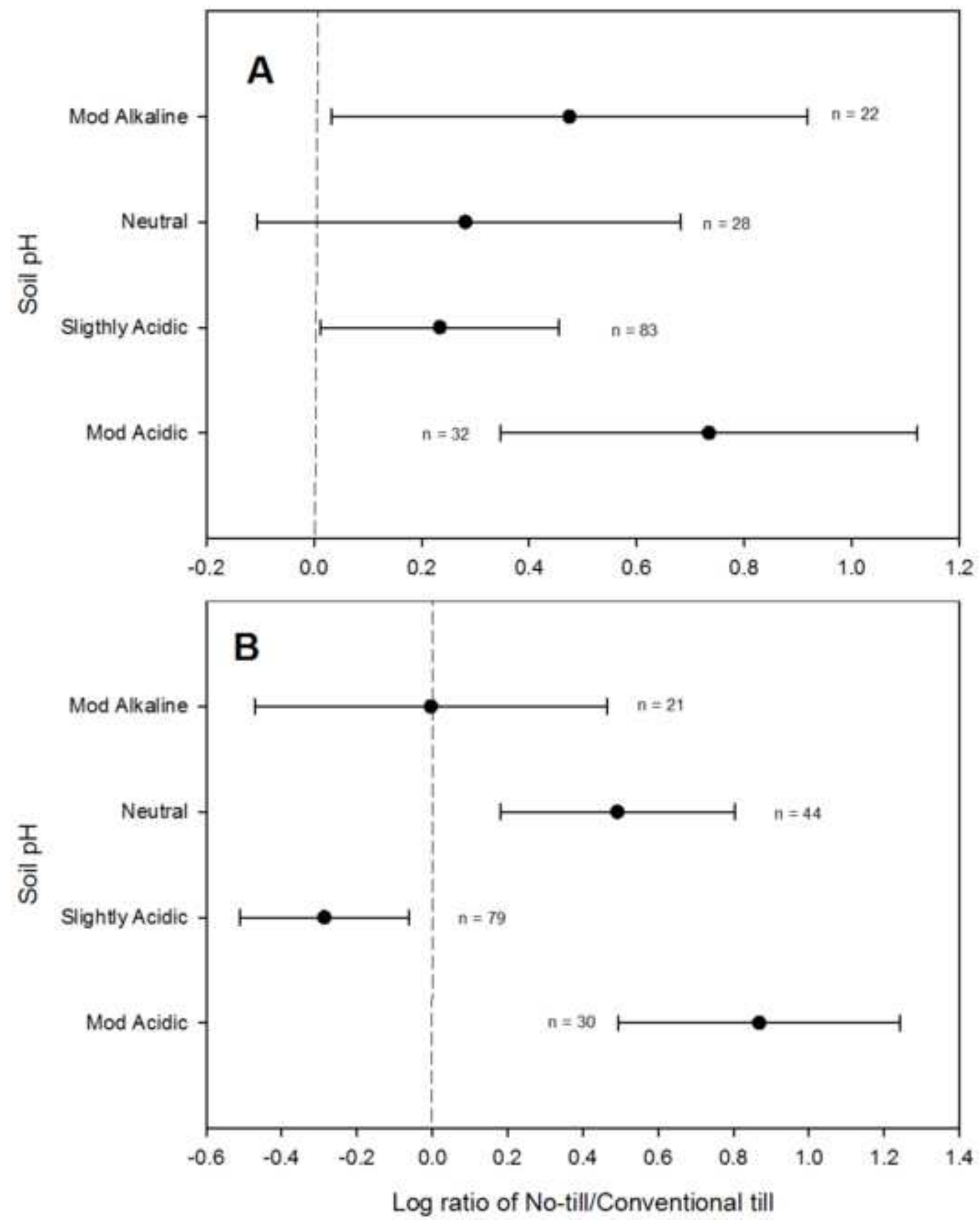

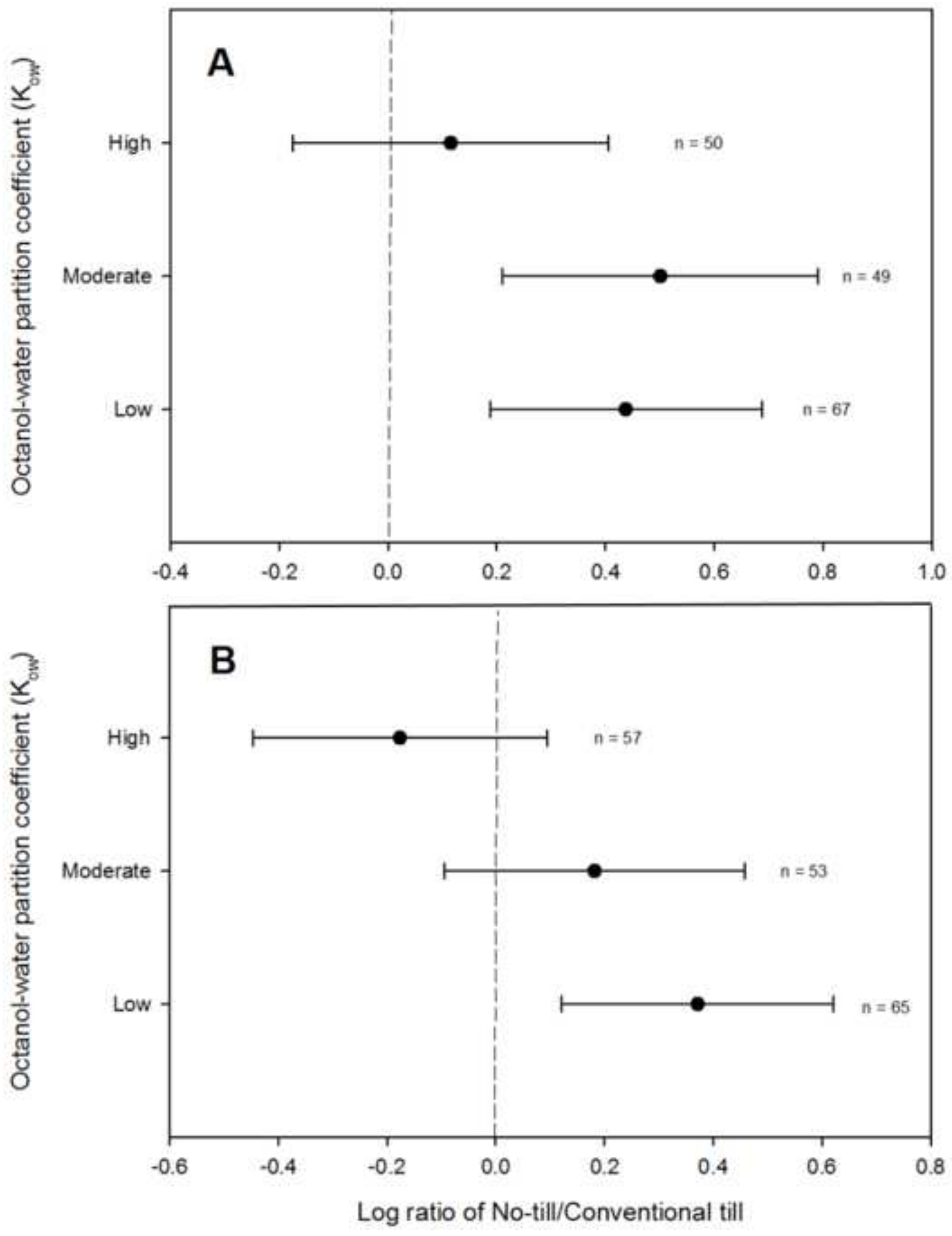

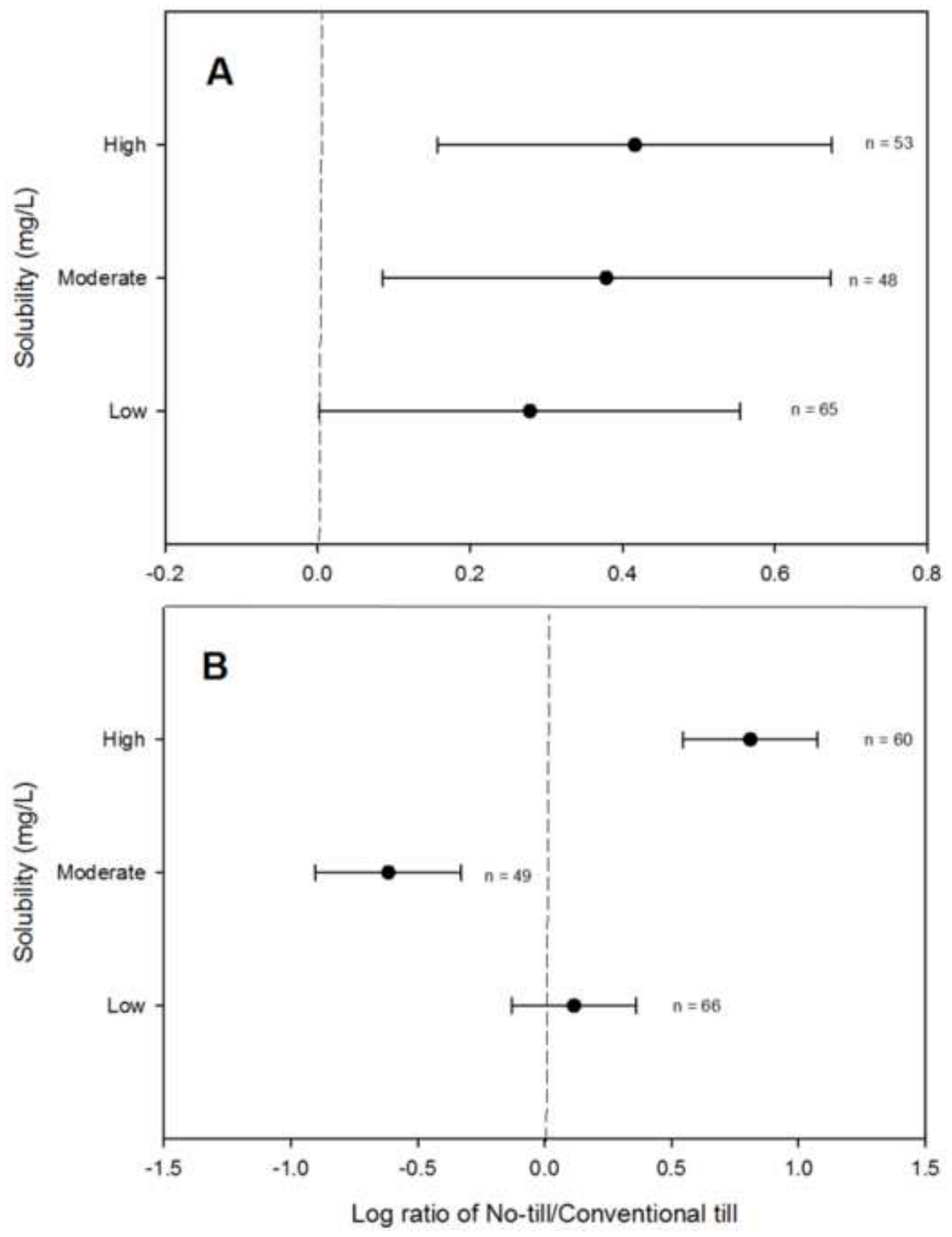
Table 1 References for pesticides concentration and load selected for the meta-analysis.

References are listed in bold if both concentration and load of pesticides are reported. References are listed in parentheses if only load is reported.

\begin{tabular}{|c|c|}
\hline Pesticide & References \\
\hline $2,4 \mathrm{D}$ & Donigian and Carsel 1987; Kenimer et al. 1987; Elliot et al. 2000 \\
\hline Alachlor & $\begin{array}{l}\text { Donigian and Carsel 1987; Sauer and Daniel 1987; Felsot et al. } 1990 \text {; Isensee and Sadeghi } 1993 \text {; Logan et al. } \\
\text { 1994; Shipitalo et al. 1997; Shipitalo and Owens 2006; Watanabe et al. 2007; Locke et al. 2008; Shipitalo et al. } \\
\text { 2008; Shipitalo and Owens } 2011\end{array}$ \\
\hline Atrazine & $\begin{array}{l}\text { Glenn and Angle 1987; Sauer and Daniel 1987; Hall et al. 1989; Hall et al. 1991; Gaynor and Bissonnette 1992; } \\
\text { Isensee and Sadeghi 1993; Logan et al. 1994; Gaynor et al. 1995; Myers et al. 1995; Pantone et al. 1996; (Triplett } \\
\text { et al. 1978; Gaynor et al. 1997; Kenimer et al. 1987; Basta et al. 1997; Shipitalo et al. 1997; Warnemuende et al. 1997; } \\
\text { Gaynor et al. 1998; Mickelson et al. 2001; Shipitalo et al. 2006; Shipitalo and Owens 2006; Watanabe et al. 2007; } \\
\text { Shipitalo and Owens 2011) }\end{array}$ \\
\hline Bentazon & Donigian and Carsel 1987 \\
\hline Bromoxynil & Elliot et al. 2000 \\
\hline Butylate & Donigian and Carsel 1987 \\
\hline Carbaryl & Donigian and Carsel 1987 \\
\hline Carbofuran & Donigian and Carsel 1987; Levanon et al. 1993 (Felsot et al. 1990) \\
\hline Chlorimuron & Locket et al. 2008 (only load) \\
\hline Chlorpyrifos & Sauer and Daniel 1987 \\
\hline Cyanazine & Hall et al. 1989; Hall et al. 1991; Isensee and Sadeghi 1993; Mickelson et al. 2001 \\
\hline Diazinon & Levanon et al. 1993 \\
\hline Dicamba & Donigian and Carsel 1987; Hall and Mumma 1994; Elliot et al. 2000 \\
\hline Diclofop & Elliot et al. 2000 \\
\hline Diuron & Lennartz et al. 1997 \\
\hline Fluometuron & Baughman et al. 2001 \\
\hline Fonofos & Donigian and Carsel 1987 \\
\hline Glufosinate & Shipitalo et al. 2008 \\
\hline Glyphosate & Warnemuende et al. 2007; Shipitalo et al. 2008; Shipitalo and Owens 2011 \\
\hline Linuron & $\begin{array}{l}\text { Donigian and Carsel 1987; Shipitalo et al. 1997; Shipitalo and Owens 2006; Shipitalo et al. 2008; Shipitalo and } \\
\text { Owens } 2011\end{array}$ \\
\hline MCPA & Elliot et al. 2000 \\
\hline Mecoprop & Elliot et al. 2000 \\
\hline Metolachlor & $\begin{array}{l}\text { Donigian and Carsel 1987; Hall et al. 1989; Hall et al. 1991; Gaynor and Bissonnette 1992; Levanon et al. 1993; } \\
\text { Logan et al. 1994; Gaynor et al. 1995; Myers et al. 1995; Mickelson et al. } 2001\end{array}$ \\
\hline Metribuzin & $\begin{array}{l}\text { Donigian and Carsel 1987; Logan et al. 1994; Shipitalo et al. 1997; Shipitalo and Owens 2006; Shipitalo et al. } \\
\text { 2008; Shipitalo and Owens } 2011\end{array}$ \\
\hline Norflurazon & Baughman et al. 2001 \\
\hline Simazine & Triplett et al. 1978; Glenn and Angle 1987; Hall et al. 1989; Hall et al. 1991; Lennartz et al. 1997 \\
\hline Toxaphene & Donigian and Carsel 1987 \\
\hline Trifluralin & Donigian and Carsel 1987 \\
\hline
\end{tabular}


Table 2 Values for each categorical variable for pesticide and soil physicochemical characteristics including solubility (Sol), octanol-water partition coefficient $\left(\mathrm{K}_{\mathrm{ow}}\right)$, organic matter content (O.M.), texture, and $\mathrm{pH}$. Categories for solubility and octanol-water partition coefficient were adapted from University of Hertfordshire, PPDB (2017). Soil texture categories were taken from Coche (1986) and Soil Science Division Staff (2017), pH values were categorized using Horneck et al. (2011) and Soil Science Division Staff (2017), and organic matter content using Soil Science Division Staff (2017) and Great Lakes Agronomy handbook (2001).

\begin{tabular}{|c|c|c|c|c|c|c|c|}
\hline & \multicolumn{2}{|c|}{ Pesticide } & \multicolumn{5}{|c|}{ Soil } \\
\hline & Sol & $\mathrm{K}_{\mathrm{ow}}$ & O.M. & & Texture & & $\mathrm{pH}$ \\
\hline Very Low & - & - & $<1.2$ & Coarse & Sand, loamy sand & Strongly acidic & $<5.1$ \\
\hline Low & $<50$ & $<2.7$ & $1.3-2.2$ & Mod. Coarse & Sandy loam & Mod. acidic & $5.2-6$ \\
\hline Moderate & $50-500$ & $2.7-3$ & $2.3-3.7$ & Medium & Loam, silty loam, silt & Slightly acidic & $6.1-6.5$ \\
\hline High & $>500$ & $>3$ & $3.8-5.2$ & Mod. Fine & $\begin{array}{l}\text { loams (clay, sandy clay, silty } \\
\text { clay) }\end{array}$ & Neutral & $6.6-7.3$ \\
\hline \multirow[t]{2}{*}{ Very High } & - & - & $>5.2$ & Fine & Sandy clay, silty clay, clay & Mod. alkaline & $7.4-8.4$ \\
\hline & & & & & & Strongly alkaline & $>8.5$ \\
\hline
\end{tabular}


Table 3 Mean, minimum and maximum concentration of pesticides $\left(\mu \mathrm{g} \mathrm{L}^{-1}\right)$ in runoff under different tillage management. Abbreviations: $\mathrm{K}_{\mathrm{ow}}=$ Octanol- water partition coefficient; $\mathrm{pKa}=$ dissociation constant; $\mathrm{MDL}=$ method detection limit $(\mathrm{MDL})$, i.e. the lowest concentration reported for a pesticide using standard methods; $\mathrm{BD}=$ below detection limit; $\mathrm{NR}=$ no concentration range (i.e. only one reported value for a particular pesticide).

\begin{tabular}{|c|c|c|c|c|c|c|c|c|c|c|}
\hline \multirow[b]{2}{*}{ Pesticide } & \multirow[b]{2}{*}{$\mathbf{K}_{\mathbf{o w}}$} & \multirow[b]{2}{*}{ pKa } & \multirow[b]{2}{*}{$\begin{array}{c}\text { Solubility } \\
\text { (mg/L) }\end{array}$} & \multirow[b]{2}{*}{$\begin{array}{c}\text { MDL } \\
(\mu \mathrm{g} / \mathrm{L})\end{array}$} & \multicolumn{3}{|c|}{ No-till } & \multicolumn{3}{|c|}{ Conventional till } \\
\hline & & & & & $\begin{array}{l}\text { Mean } \\
(\mu \mathrm{g} / \mathrm{L})\end{array}$ & $\underset{(\mu \mathrm{g} / \mathrm{L})}{\operatorname{Min}}$ & $\underset{(\mu \mathrm{g} / \mathrm{L})}{\operatorname{Max}}$ & $\begin{array}{l}\text { Mean } \\
(\mu \mathrm{g} / \mathrm{L})\end{array}$ & $\underset{(\mu \mathrm{g} / \mathrm{L})}{\operatorname{Min}}$ & $\underset{(\mu \mathrm{g} / \mathrm{L})}{\operatorname{Max}}$ \\
\hline Simazine & 2.3 & 1.62 & 5 & 0.05 & 30.92 & $\mathrm{BD}$ & 320 & 19.98 & 0.2 & 150 \\
\hline Norflurazon & 2.45 & - & 34 & 13 & 131.05 & 114.5 & 147.6 & 134.55 & 114.5 & 154.6 \\
\hline Metribuzin & 1.65 & 0.99 & 1165 & 0.06 & 15.81 & 0.03 & 41.1 & 5.23 & 0.21 & 18.1 \\
\hline Metolachlor & 3.4 & - & 530 & 0.02 & 2750.95 & 0.3 & 54600 & 2962.12 & 0.3 & 64100 \\
\hline Mecoprop & -0.19 & 3.11 & 250000 & 0.05 & 3.32 & 0.22 & 8.64 & 0.98 & 0.21 & 2.46 \\
\hline MCPA & -0.81 & 3.73 & 29390 & 0.05 & 0.78 & 0.24 & 1.81 & 0.67 & 0.13 & 1.18 \\
\hline Linuron & 3 & - & 63.8 & 0.13 & 62.98 & 1.7 & 108.9 & 23.91 & 5.2 & 51.7 \\
\hline Glyphosate & -3.2 & 2.34 & 10500 & 1 & 46.92 & 8.9 & 235.3 & 40.2 & 3.1 & 182.4 \\
\hline Glufosinate & -3.96 & 2 & - & 2.5 & 7.2 & NR & NR & 33.9 & NR & NR \\
\hline Fonofos & 3.9 & - & 13 & NR & 1.3 & NR & NR & 3.9 & NR & NR \\
\hline Fluometuron & 2.28 & - & 111 & 14 & 232.5 & 185 & 280 & 229 & 141.2 & 316.8 \\
\hline Diuron & 2.87 & - & 35.6 & 0.05 & 30.5 & 13.7 & 47.3 & 7.85 & 7.7 & 8 \\
\hline Diclofop & 1.61 & 3.43 & 122700 & 0.05 & 0.49 & 0.28 & 0.86 & 0.28 & 0.13 & 0.52 \\
\hline Dicamba & -1.88 & 1.87 & 250000 & 2 & 2.85 & $\mathrm{BD}$ & 7.52 & 6.13 & 0.07 & 23.46 \\
\hline Diazinon & 3.69 & 2.6 & 60 & $<0.01$ & 2200 & NR & NR & 3100 & NR & NR \\
\hline Cyanazine & 2.1 & 12.9 & 171 & 0.1 & 22.8 & 0.5 & 110 & 7.59 & 0.2 & 38 \\
\hline Chlorpyrifos & 4.7 & - & 1.05 & 0.05 & 0.9 & 0.21 & 1.59 & 0.62 & 0.59 & 0.64 \\
\hline Carbofuran & 1.8 & - & 322 & 0.02 & 12453.35 & 6.7 & 24900 & 49806.4 & 12.8 & 99600 \\
\hline Carbaryl & 2.36 & 10.4 & 9.1 & NR & 2.5 & NR & NR & 6.8 & NR & NR \\
\hline Butylate & 4.1 & - & 45 & NR & BD & NR & NR & 0.6 & NR & NR \\
\hline Bromoxynil & 0.27 & 3.86 & 38000 & 0.05 & 0.17 & $\mathrm{BD}$ & 0.23 & 0.18 & $\mathrm{BD}$ & 0.39 \\
\hline Bentazon & -0.46 & 3.51 & 7112 & NR & 3.6 & NR & NR & 11.6 & NR & NR \\
\hline Atrazine & 2.7 & 1.7 & 35 & 0.03 & 3573.24 & $\mathrm{BD}$ & 130700 & 3819.32 & 1 & 150100 \\
\hline Alachlor & 3.09 & 0.62 & 240 & 0.1 & 237.37 & 0.2 & 1564 & 145.01 & 1 & 1830 \\
\hline $2,4-\mathrm{D}$ & -0.82 & 3.4 & 24300 & 0.5 & 1.62 & 0.5 & 4.3 & 3.6 & 0.14 & 9.6 \\
\hline
\end{tabular}


Table 4 Mean, minimum and maximum load of pesticides $\left(\mathrm{g} \mathrm{ha}^{-1}\right)$ in runoff under different tillage management. Abbreviations: $\mathrm{K}_{\mathrm{ow}}=$ octanol- water partition coefficient; $\mathrm{pKa}=$ dissociation constant $\mathrm{BD}=$ below detection limit $\mathrm{NR}=$ no concentration range (i.e. only one reported value for a particular pesticide). (*) Mean value not calculated.

\begin{tabular}{|c|c|c|c|c|c|c|c|c|c|c|}
\hline \multirow{2}{*}{ Pesticide } & \multirow[b]{2}{*}{$\mathbf{K}_{\text {ow }}$} & \multirow[b]{2}{*}{ pKa } & \multirow[b]{2}{*}{$\begin{array}{l}\text { Solubility } \\
\text { (mg/L) }\end{array}$} & \multirow[b]{2}{*}{$\begin{array}{l}\text { MDL } \\
(\mu \mathrm{g} / \mathrm{L})\end{array}$} & \multicolumn{3}{|c|}{ No-till } & \multicolumn{3}{|c|}{ Conventional till } \\
\hline & & & & & $\begin{array}{l}\text { Mean } \\
(\mu \mathrm{g} / \mathrm{L})\end{array}$ & $\underset{(\mu \mathrm{g} / \mathrm{L})}{\operatorname{Min}}$ & $\underset{(\mu \mathrm{g} / \mathrm{L})}{\operatorname{Max}}$ & $\begin{array}{l}\text { Mean } \\
(\mu \mathrm{g} / \mathrm{L})\end{array}$ & $\underset{(\mu \mathrm{g} / \mathrm{L})}{\operatorname{Min}}$ & $\underset{(\mu \mathrm{g} / \mathrm{L})}{\operatorname{Max}}$ \\
\hline Simazine & 2.3 & 1.62 & 5 & 0.05 & 14.68 & 0.01 & 141 & 5.59 & 0.01 & 27 \\
\hline Norflurazon & 2.45 & - & 34 & 13 & 71 & 70 & 71 & 71 & 60 & 81 \\
\hline Metribuzin & 1.65 & 0.99 & 1165 & 0.06 & 2.34 & $\mathrm{BD}$ & 16 & 0.17 & $\mathrm{BD}$ & 0.31 \\
\hline Metolachlor & 3.4 & - & 530 & 0.02 & 14.4 & 0.01 & 116.67 & 13 & 0.02 & 139 \\
\hline Mecoprop & -0.19 & 3.11 & 250000 & 0.05 & 1.02 & $<0.01$ & 3.06 & 0.12 & 0 & 0.34 \\
\hline MCPA & -0.81 & 3.73 & 29390 & 0.05 & 0.19 & $<0.01$ & 0.55 & 0.04 & 0 & 0.12 \\
\hline Linuron & 3 & - & 63.8 & 0.13 & 8.46 & 3.25 & 19.49 & 1.67 & 0.85 & 3.25 \\
\hline Glyphosate & -3.2 & 2.34 & 10500 & 1 & 54.24 & 50.34 & 58.14 & 23 & 20.56 & 24.82 \\
\hline Glufosinate & -3.96 & 2 & - & 2.5 & 1.01 & 0.27 & 2 & 0.55 & 0.55 & 0.98 \\
\hline Fluometuron & 2.28 & - & 111 & 14 & 112 & 89 & 135 & 120 & 74 & 166 \\
\hline Diuron* & 2.87 & - & 35.6 & 0.05 & & 2.24 & & & 1.25 & \\
\hline Diclofop & 1.61 & 3.43 & 122700 & 0.05 & 0.02 & $<0.01$ & 0.07 & 0.02 & $<0.01$ & 0.06 \\
\hline Dicamba & -1.88 & 1.87 & 250000 & 2 & 8.09 & $\mathrm{BD}$ & 31.2 & 0.71 & $<0.01$ & 3.3 \\
\hline Cyanazine & 2.1 & 12.9 & 171 & 0.1 & 13.16 & $<0.01$ & 106.2 & 4.52 & 0.02 & 22.9 \\
\hline Chlorpyrifos & 4.7 & - & 1.05 & 0.05 & 0.11 & 0.02 & 0.2 & 0.25 & 0.2 & 0.3 \\
\hline Chlorimuron* & 2.5 & 4.2 & 1200 & $<0.01$ & & 6.48 & & & 0.81 & \\
\hline Carbofuran & 1.8 & - & 322 & 0.02 & 43.85 & 26 & 62 & 66.8 & 12 & 121 \\
\hline Bromoxynil & 0.27 & 3.86 & 38000 & 0.05 & 0.02 & $<0.01$ & 0.04 & 0.01 & $<0.01$ & 0.03 \\
\hline Atrazine & 2.7 & 1.7 & 35 & 0.03 & 24.05 & $<0.01$ & 161.5 & 16 & 0.05 & 137.04 \\
\hline Alachlor & 3.09 & 0.62 & 240 & 0.1 & 15.13 & $<0.01$ & 166 & 26.41 & 0.03 & 219.7 \\
\hline $2.4 \mathrm{D}$ & -0.82 & 3.4 & 24300 & 0.5 & 0.08 & $<0.01$ & 0.19 & 0.38 & $<0.01$ & 1.42 \\
\hline
\end{tabular}

